\title{
Car Carrier Operation Mode Innovation and Development Path
}

\author{
Pan Deng \\ Logistics Management Institute, Hunan Vocational College of Modern Logistics, Changsha 410001, China \\ 49849977@qq.com
}

Keywords: car free carrier; platform scale operation; profit mode.

Abstract: The construction of the operation mode of the car free carrier is the integration of Internet technology in the development of the IOT industry, so that our country's road freight can find a new direction of development. Therefore, the innovation of carrier free carrier operation is based on the existing work mode and the problems arising in the current operation process, to find the path of innovation work and realize the innovation and development.

\section{Introduction}

Road freight is the key to the development of the logistics industry and an integral part of the comprehensive transportation system. Integrating the Internet into road freight is to enable the carrier to use the Internet, borrow management mode, dispatch vehicles and use all kinds of resources. As a result, resources integration can be realized, industry construction can be standardized, breakthroughs in the development of industries can be broken through, and a good foundation for the transformation of road freight will be laid.

\section{The Necessity of the Development of the Car Carrier}

Table 1. The difference between a car carrier and a freight forwarder

\begin{tabular}{ccc}
\hline & Car free carrier & Freight forwarder \\
\hline Conclude a contract & Sure & May not \\
Full cost & Sure & May not \\
Commission & May not & Sure \\
Freight differential & Sure & May not \\
\hline
\end{tabular}

Table 2. Characteristics of car free carrier

\begin{tabular}{|c|c|}
\hline Characteristic & Concrete content \\
\hline $\begin{array}{l}\text { With advanced ideas and rich } \\
\text { management experience }\end{array}$ & $\begin{array}{l}\text { Build a knowledge pioneer mode and get rich experience } \\
\text { in practice }\end{array}$ \\
\hline $\begin{array}{l}\text { Realization of the integration of } \\
\text { scattered Logistics }\end{array}$ & $\begin{array}{l}\text { Using information network, Mastering a large number of } \\
\text { resources and integrating all resources }\end{array}$ \\
\hline $\begin{array}{l}\text { Low cost, rapid expansion of service } \\
\text { scope }\end{array}$ & $\begin{array}{l}\text { Businesses and Individuals do not need to buy vehicles, } \\
\text { So the cost of vehicles is negligible, So that funds can be } \\
\text { used in other jobs }\end{array}$ \\
\hline
\end{tabular}

A car free carrier is an individual and an enterprise that does not transport vehicles but is engaged in road transportation. It is quite different from the freight forwarder mode (as shown in Table 1), and its development has also formed distinctive features (as shown in Table 2). The car carrier is the inevitable development trend of the road freight in the present social development background, which has historical inevitability, and its development will provide help for the development of the logistics and transportation industry, and make clear the direction of the development of the industry. That is, it will improve the governance of the industry, strengthen the supervision of the industry, and let the 
industry realize the transformation in the current level. At the same time, the car carrier has also promoted the communication between the two parties. Many of the links in the middle are cancelled, effectively reducing the transaction cost of using [1].

\section{Innovation and Development of the Model of Car Free Carrier}

The innovation of vehicle carrier model is based on the current situation (shown in Table 3) to find innovative ways to speed up the development of the model and logistics industry.

Table 3. Operation status of car free carrier model

\begin{tabular}{cc}
\hline Present situation & performance \\
\hline $\begin{array}{c}\text { Not yet a stable business model and } \\
\text { scale }\end{array}$ & $\begin{array}{c}\text { There are many problems in operation, including the } \\
\text { lack of law and supervision. These have led to a unified } \\
\text { standard for the business of car free carriers, and the } \\
\text { industry has not been established. }\end{array}$ \\
$\begin{array}{c}\text { The profit model needs to be } \\
\text { clarified }\end{array}$ & $\begin{array}{c}\text { Many domestic car carriers are still inject capital, the } \\
\text { market profit is not clear, and the carrier will conduct } \\
\text { private transactions }\end{array}$ \\
\hline
\end{tabular}

Thus, the realization of innovation and development is the establishment of platform scale, the determination of profit models and the improvement of corresponding systems (as shown in Table 4).

Table 4. Operation mode and innovation of car free carrier

\begin{tabular}{cc}
\hline Operation mode & Innovative ways \\
\hline After all the carrier carrier is made up of the actual & $\begin{array}{c}\text { Establish a platform scale operation } \\
\text { mode, build a diversified profit } \\
\text { carrier pool, the owner chooses the carrier from it and } \\
\text { reaches the request, and then the carrier signed an } \\
\text { electronic contract with the consignee and the owner to } \\
\text { carry out the transportation of the actual goods }\end{array}$ \\
\hline
\end{tabular}

\subsection{Realizing the scale operation of the platform}

The realization of platform scale operation is to establish a unified platform, which will form a certain scale to provide more professional services. In this regard, the way to achieve this is to increase capital investment and increase the publicity of content [2]. The operation of a car carrier will ignore assets and pay attention to capital. If you want to enter the market, a lot of money must be invested in the early construction. After the overall scale is concentrated, it will be profitable from the operation. To strengthen the propaganda is to take the owner and the transporter as the object, to understand their needs and preferences, to provide targeted services, to rely on the platform, to adapt to the market rules, to reduce the cost used in both sides of the transaction and to complete the transition to specialization. At the same time, the construction of platform should change the way of building single platform, realize the professional development of platform, and establish Platform Alliance.

\subsection{Building a multiple profit model}

Enterprises can get profits from two aspects, one is basic services, the other is value-added services. The two is value-added services. There are obvious differences between the types of goods in actual transportation and the corresponding business information. Therefore, the cost of each transportation is uncertain. As a whole, there are decreasing and increasing changes, so different cost prices will be set for different businesses. Based on the platform scale operation, the financing mode is set up, requiring enterprises to finance with less cost. Scientific handling of all kinds of business, including insurance, refueling and maintenance, is to make it more profitable and diversified on the basis of existing services. At the same time, we must complete the analysis of big data, collect dynamic data of vehicles and goods, track vehicles in real time, strengthen network perception and 
optimize the use of platforms.

\subsection{Perfect the system}

At present, the model of car carrier is still in the initial stage, and has not made clear laws and regulations to restrict its behavior, and through the pre pilot policy, it is a problem that appears after the operation of the enterprise, and keeps track of the whole process in order to find a solution for the new problem. In this regard, the improvement of the system is to define the standards for the use of transport vehicles, and access them to the platform, with relevant personnel, vehicles and other information in the platform. The purpose of system formulation and implementation is to promote the development of car carrier, and also to promote the development of technology. So, at the same time, we should improve the technical level, including data collection, data analysis, real-time tracking and so on. Through technical assistance, reduce the mechanized operation of personnel, control costs, and achieve comprehensive control.

\section{Conclusion}

To realize the innovation of the car carrier operation mode and speed up its development, it is a continuous summary of the problems in the process of development, the historical inevitability of its emergence, and the solutions to the problems, that is to realize the scale operation of the platform, build a multiple profit model, and increase the investment of technology. By these ways, it can expand the business operation of the enterprise. Scale, determine the way of enterprise development, realize the intensification of resources, at the same time, realize the norms and specialties of pattern development and management.

\section{References}

[1] Potier O, Brun J, Masson P L, et al. How Innovative Design can contribute to Chemical and Process Engineering development? Opening new innovation paths by applying the C-K method[J]. Chemical Engineering Research \& Design, 2015, 103:108-122.

[2] Carcary M, Doherty E, Thornley C. Business Innovation and Differentiation: Maturing the IT Capability [J]. It Professional, 2015, 17(2):46-53.

[3] Liu H, Wang Z, Long Y, et al. Let Feds Monitor Carriers: State oversight of insurance encourages complexity and stifles innovation.(conversation with Joe Beneducci of Fireman's Fund Insurance Co.)(Interview)[J]. Energy, 2015, 89(May):1010-1017.

[4] Naudin C, Carof M, Celette F, et al. Training aimed at promoting innovation and its evaluation in agriculture: using expert skills acquired through research as education tools in agronomy[J]. Fourrages, 2015, 217(217):91-99. 